Tersedia online di: http://ejournal-balitbang.kkp.go.id/index.php/jra

\title{
BUDIDAYA RUMPUT LAUT Sargassum sp. DENGAN METODE KANTONG PADA BEBERAPA TINGKAT KEDALAMAN DI DUA WILAYAH PERAIRAN BERBEDA
}

\author{
Muslimin ${ }^{\#}$ dan Wiwin Kusuma Perdana Sari \\ Loka Riset Budidaya Rumput Laut \\ (Naskah diterima: 18 Juli 2017; Revisi final: 6 Oktober 2017; Disetujui publikasi: 6 Oktober 2017)
}

\begin{abstract}
ABSTRAK
Optimalisasi produksi rumput laut memerlukan teknologi budidaya yang tepat. Rumput laut Sargassum sp. mudah mengalami kerontokan talus. Hal inilah yang melatarbelakangi perlunya kajian penerapan metode kantong untuk budidaya rumput laut Sargassum sp. Tujuan penelitian ini adalah untuk mengetahui respons pertumbuhan rumput laut Sargassum sp. yang dibudidayakan dengan metode kantong pada beberapa tingkat kedalaman. Penelitian dilakukan di dua lokasi berbeda yakni perairan Kabupaten Pohuwato Provinsi Gorontalo dan perairan Kabupaten Bolaang Mongondow Utara Provinsi Sulawesi Utara pada bulan MaretMei 2016. Desain penelitian menggunakan RAL faktorial yang terdiri atas faktor wadah kantong (tanpa kantong, wadah kantong dengan ukuran mata jaring 1,5; 0,75; dan 0,25 inci) dan kedalaman (permukaan 0; 50; 100; 150; dan $200 \mathrm{~cm}$ ) masing-masing diulang lima kali. Hasil penelitian menunjukkan bahwa faktor wadah kantong dan kedalaman, serta interaksi keduanya berpengaruh terhadap pertumbuhan rumput laut Sargassum sp. pada taraf uji 5\%( $(\mathrm{P}<0,05)$ di kedua lokasi penelitian. Pertumbuhan terbaik diperoleh dari perlakuan KODO (tanpa kantong dan di permukaan air) sedangkan pertumbuhan terendah terjadi pada perlakuan K3D4 (kantong meshsize 0,25 inci pada kedalaman $200 \mathrm{~cm}$ ). Bobot tertinggi di lokasi-I mencapai $235,8 \mathrm{~g}$ dan terendah 19,2 g; sedangkan di lokasi-II tertinggi 208,4 g dan terendah 42,2 g. Penggunaan kantong rumput laut kurang efektif dalam memacu pertumbuhan rumput laut Sargassum sp. Pertumbuhan sangat dipengaruhi oleh intensitas cahaya, karenanya budidaya Sargassum sp. perlu memperhatikan faktor kedalaman perairan yang berkorelasi dengan intensitas cahaya matahari.
\end{abstract}

KATA KUNCl: budidaya; metode kantong; kedalaman; rumput laut Sargassum sp.

ABSTRACT: The growth rate of Sargassum sp. cultured using bag method with different mesh sizes, depth levels and locations. By: Muslimin and Wiwin Kusuma Perdana Sari

Optimization of seaweed production requires an appropriate cultivation technology. The thallus of Sargassum sp. is easy to break. This was the underlying reason to study the application of bag method in cultivating Sargassum sp. The research aimed to find out the growth response of Sargassum sp. cultivated using bag method at various depth levels. The research was conducted in two different locations, namely Pohuwato Regency Gorontalo and North Bolaang Mongondow Regency North Sulawesi from M arch to M ay 2016. The experiment was carried out using the factorial design, consisting of bag factor (without bag; mesh size bag of 1.5; 0.75 ; and 0.25 inches) and depth factor (surface $0 ; 50 ; 100 ; 150 ;$ and $200 \mathrm{~cm}$ ) with five replications. Results of the research showed that both parameters (bag and the depth factor) and their interaction have affected the growth of Sargassum sp. at $5 \%$ confidencelevel $(P<0.05)$ in both locations. The highest growth response was found in KODO treatment (without bag on the water surface) whereas the lowest growth was showed by K3D4 treatment (mesh size bag of 0.25 inches at $200 \mathrm{~cm}$ depth). The highest weight at location-I was $235.8 \mathrm{~g}$ and the lowest weight was $19.2 \mathrm{~g}$. In location-II, the highest weight was $208.4 \mathrm{~g}$ and the lowest was $42.2 \mathrm{~g}$. The use of bags was ineffective in boosting the growth of cultured Sargassum sp. The growth of seaweed is strongly influenced by the intensity of light. Therefore, it is recommended that the cultivation of Sargassum sp. should consider the relationship between the water depth factor and the intensity of sunlight

KEYWORDS: cultivation; bag method; depth; seaweed; Sargassum sp.

\footnotetext{
\# Korespondensi: Loka Riset Budidaya Rumput Laut.

JI. Pelabuhan Etalase Perikanan, Desa Tabulo Selatan Kec.

Mananggu Kab. Boalemo Gorontalo 96265, Indonesia.

E-mail: mimin_69@yahoo.com
} 


\section{PENDAHULUAN}

Sargassum sp. merupakan jenis rumput laut paling melimpah dari kelompok alga coklat (Phaeophyceae) yang tersebar di perairan tropis, termasuk di Indonesia. Lingkungan tempat tumbuh Sargassum terutama di daerah perairan yang jernih dengan substrat dasar batu karang, karang mati, batuan vulkanik, dan bendabenda yang bersifat massive yang berada di dasar perairan. Sargassum tumbuh di daerah intertidal, subtidal, sampai daerah tubir dengan ombak besar dan arus keras. Kedalaman untuk pertumbuhan dari 0,5$10 \mathrm{~m}$. Sargassum dapat tumbuh sepanjang tahun, bersifat perenial atau setiap musim barat maupun timur dapat dijumpai di berbagai perairan (Kadi, 2005).

Sargassum sp. seperti halnya makroalga coklat lainnya juga mengandung senyawa bioaktif yang dapat digunakan sebagai ekstrak atau sebagai komponen utama pada industri makanan dan farmasi. Polisakarida hasil isolasi spesies alga coklat yakni alginat dan fukoidan. Alginat banyak diekstrak dan digunakan pada industri makanan, medis, dan beberapa proses industri sebagai pembentuk gel dan stabiliser (Redmon et al., 2014). Fukoidan telah diteliti berfungsi sebagai anti tumor, anti metastasis, anti proliferasi, anti virus, dan anti inflamasi pada percobaan di laboratorium (Nisizawa, 2002).

Secara umum rumput laut Sargassum sp. belum banyak dikenal dan dimanfaatkan di Indonesia dibanding jenis rumput laut lainnya yang lebih populer. Produksinya masih didapat secara alamiah. Beberapa negara lain telah lebih familiar dengan rumput laut Sargassum ini dan banyak melakukan penelitianpenelitian untuk mengetahui berbagai aspek rumput laut Sargassum sp. Liang et al. (2013) menyebutkan bahwa S. thunbergii telah banyak digunakan di Cina sebagai sumber pakan terpenting bagi budidaya teripang Apostichopus japonicus selama 10 tahun terakhir ini.

Kabupaten Pohuwato merupakan salah satu lokasi percontohan pengembangan kawasan minapolitan di Provinsi Gorontalo dengan komoditas unggulan rumput laut dan udang. Suhaimi et al. (2012) melaporkan bahwa berdasarkan hasil survai kondisi perairan Kabupaten Pohuwato pada 45 titik pengamatan, terlihat bahwa secara umum perairan Kabupaten Pohuwato memiliki kondisi yang memungkinkan untuk budidaya rumput laut.

Kabupaten Bolaang Mongondow Utara adalah kabupaten baru hasil pemekaran di Provinsi Sulawesi Utara. Perhatian pemerintah daerah Kabupaten Bolaang Mongondow Utara terkonsentrasi pada pengembangan pertanian dan perikanan laut. Luasnya perairan pantai yang mencapai $7.600 \mathrm{~km}^{2}$ dengan panjang garis pantai $174 \mathrm{~km}$ menjadikan Kabupaten Bolaang Mongondow Utara memiliki potensi budidaya rumput laut yang besar (Puslat KP, 2011). Sambuari et al. (2015) melaporkan hasil penelitian mengenai analisis sektor basis di Kabupaten Bolaang Mongondow Utara bahwa sektor perikanan di Kabupaten Bolaang Mongondow memiliki potensi cukup baik tetapi masih lebih rendah dibandingkan sektor pertanian tanaman pangan dan perkebunan.

Perairan Kabupaten Pohuwato dan Kabupaten Bolaang Mongondow Utara dipilih sebagai lokasi penelitian ini untuk mengetahui potensi perairan tersebut bagi budidaya rumput laut Sargassum sp. Perairan Kabupaten Pohuwato yang merupakan bagian dari kawasan Teluk Tomini memiliki karakter perairan yang berbeda dengan perairan Kabupaten Bolaang Mongondow Utara yang berbatasan langsung dengan laut terbuka. Perbedaan karakter perairan di kedua lokasi diharapkan mampu memberikan informasi yang cukup bagi perkembangan budidaya rumput laut Sargassum sp.

Terbatasnya teknologi budidaya rumput laut Sargassum sp. dengan metode yang tepat menyebabkan belum optimal produksinya. Rumput laut Sargassum sp. mudah mengalami kerontokan terutama pada bagian talus serupa daun (blade) yang merupakan salah satu kendala yang dihadapi dalam upaya budidayanya. $\mathrm{Hal}$ ini memunculkan gagasan untuk mengkaji penerapan metode kantong untuk mengurangi risiko tersebut. Kajian budidaya rumput laut Sargassum sp. dengan metode kantong dan penempatannya pada beberapatingkat kedalaman akan menambah informasi mengenai metode yang tepat dan sesuai untuk mengembangkan budidaya rumput laut Sargassum sp. Tujuan penelitian ini adalah untuk mengetahui respons pertumbuhan rumput laut Sargassum sp. yang dibudidayakan dengan metode kantong pada beberapa tingkat kedalaman.

\section{BAHAN DAN METODE}

\section{Lokasi dan Waktu Penelitian}

Penelitian dilakukan di dua lokasi yakni di Perairan Desa Bumbulan, Kecamatan Paguat Kabupaten Pohuwato Provinsi Gorontalo (lokasi-I) dan di Perairan Desa Tuntung Timur Kecamatan Pinogaluman Kabupaten Bolaang Mongondow Utara Provinsi Sulawesi Utara (lokasi-II) (Gambar 1) pada bulan MaretMei 2016. Kedua lokasi memiliki perbedaan karakter perairan, yakni perairan teluk semi tertutup (lokasi-I) dan perairan laut terbuka (lokasi-II). 

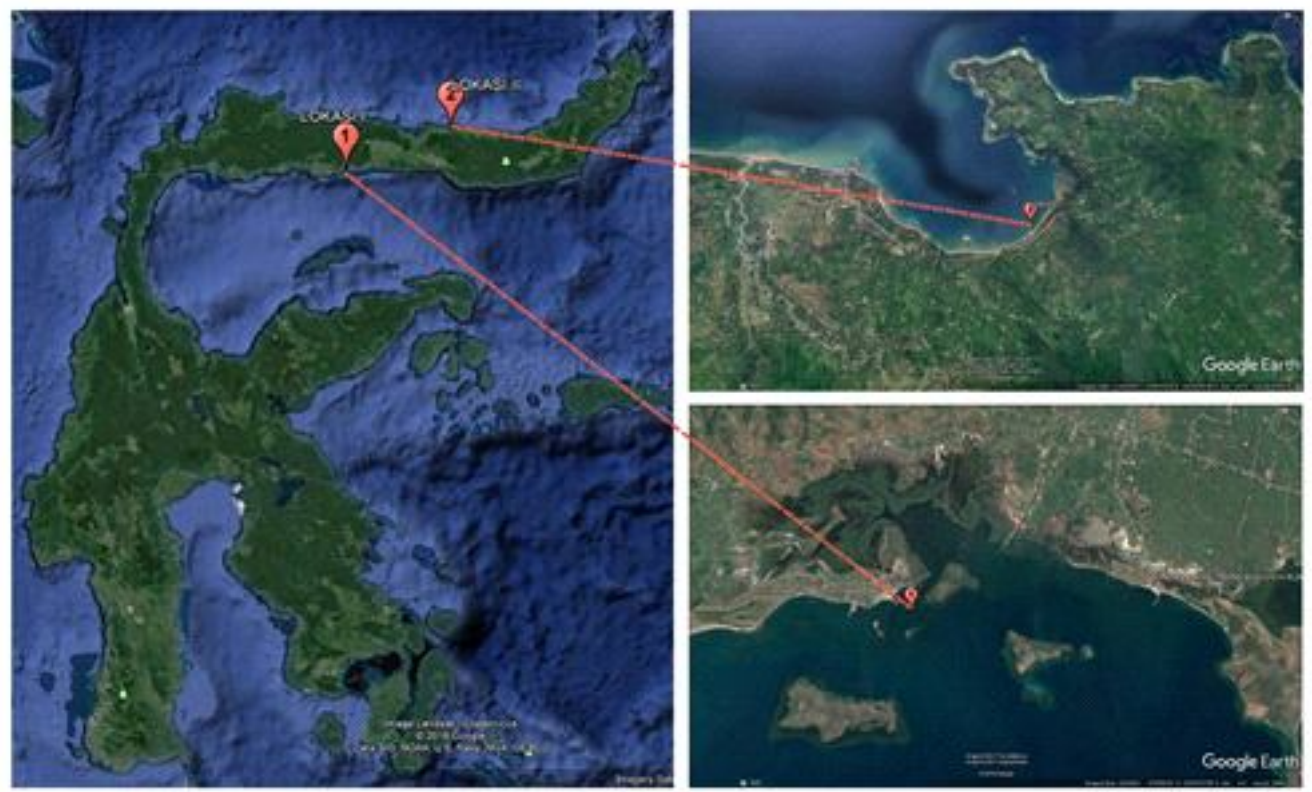

Gambar 1. Peta lokasi penelitian di Kabupaten Pohuwato (1) dan Kabupaten Bolaang Mongondow Utara (2).

Figure 1. Research locations in Pohuwato Regency (1) and North Bolaang Mongondow Regency (2).

\section{Rancangan dan Unit Percobaan}

Rancangan percobaan yang digunakan adalah Rancangan Acak Lengkap Faktorial (RALF) yang terdiri atas faktor wadah kantong (K) yaitu tanpa kantong (K0), kantong dengan ukuran mata jaring 1,5 inci (K1); 0,75 inci (K2); dan 0,25 inci (K3), dan faktor kedalaman (D) yaitu permukaan $0 \mathrm{~cm}(\mathrm{D}-0)$; kedalaman $50 \mathrm{~cm}$ (D1); $100 \mathrm{~cm}$ (D2); $150 \mathrm{~cm}$ (D3); dan $200 \mathrm{~cm}$ (D4). Terdapat 20 unit perlakuan seperti tercantum pada Tabel1.

Tabel 1. Unit perlakuan penelitian

Table 1. Treatment applications used in the study
Kantong rumput laut dibuat berbentuk tabung dengan ukuran diameter $25 \mathrm{~cm}$ dan tinggi $50 \mathrm{~cm}$. Rumput laut Sargassum sp. ditimbang $100 \mathrm{~g}$ per rumpun sebagai bobot awal tiap perlakuan kemudian diikatkan pada dasar kantong menghadap ke atas (Gambar 2). Posisi ini mirip dengan posisi alami Sargassum sp. yang melekat pada substrat di habitat alaminya. Bibit rumput laut yang digunakan diambil beserta sebagian substratnya yang masih menempel untuk memenuhi syarat tumbuh Sargassum sp. yang perlu substrat.

\begin{tabular}{|c|c|c|c|c|c|}
\hline & DO & D1 & D2 & D3 & D4 \\
\hline & $\begin{array}{l}\text { Permukaan } 0 \mathrm{~cm} \\
\text { On surface } 0 \mathrm{~cm}\end{array}$ & $\begin{array}{l}\text { Kedalaman } 50 \mathrm{~cm} \\
\text { Depth of } 50 \mathrm{~cm}\end{array}$ & $\begin{array}{l}\text { Kedalaman } 100 \mathrm{~cm} \\
\text { Depth of } 100 \mathrm{~cm}\end{array}$ & $\begin{array}{l}\text { Kedalaman } 150 \mathrm{~cm} \\
\text { Depth of } 150 \mathrm{~cm}\end{array}$ & $\begin{array}{l}\text { Kedalaman } 200 \mathrm{~cm} \\
\text { Depth of } 200 \mathrm{~cm}\end{array}$ \\
\hline KO & & & & & \\
\hline $\begin{array}{c}\text { Tanpa kantong } \\
\text { Without bag } \\
\text { K1 }\end{array}$ & KODO & K0D1 & KOD2 & K0D3 & K0D4 \\
\hline $\begin{array}{c}\text { Kantong mata jaring } 1 \frac{1}{2} " \\
\text { Bag with mesh size } 1 \frac{1}{2} 2^{\prime \prime} \\
\text { K2 }\end{array}$ & K1D0 & K1D1 & K1D2 & K1D3 & K1D4 \\
\hline $\begin{array}{c}\text { Kantong mata jaring } 3 / 4^{\prime \prime} \\
\text { Bag with mesh size } 3 / 4^{\prime \prime} \\
\text { K3 }\end{array}$ & K2D0 & K2D1 & K2D2 & K2D3 & K2D4 \\
\hline $\begin{array}{c}\text { Kantong mata jaring } 1 / 4 " \\
\text { Bag with mesh size } 1 / 4 "\end{array}$ & K3D0 & K3D1 & K3D2 & K3D3 & K3D4 \\
\hline
\end{tabular}




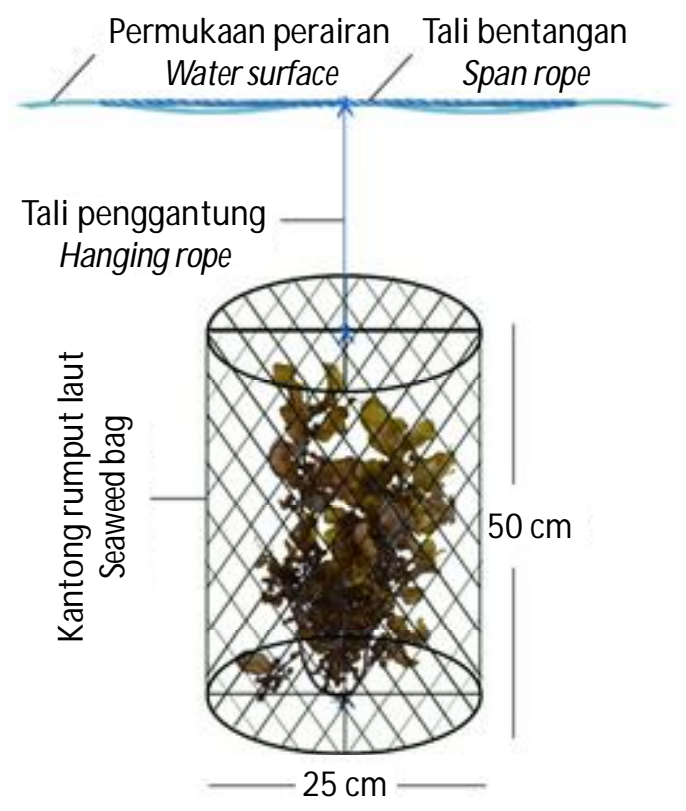

Gambar 2. Desaın kantong rumput laut.

Figure 2. Seaweed bag design.

Konstruksi budidaya rumput laut Sargassum sp. berbentuk persegi panjang berukuran $25 \mathrm{~m} \times 10 \mathrm{~m}$, terbuat dari tali polietilen yang dipancangkan dengan jangkar beton. Dalam konstruksi budidaya tersebut terdapat lima tali bentangan yang merupakan ulangan dalam penelitian ini. Setiap tali bentangan dipasang dengan jarak masing-masing $2 \mathrm{~m}$. Desain konstruksi budidaya rumput laut disajikan pada Gambar 3.

\section{Pengumpulan dan Analisis Data}

Periode budidaya rumput laut Sargassum sp. dilakukan selama 45 hari. Parameter utama yang diukur pada penelitian ini yakni bobot rumput laut pada akhir pemeliharaan dengan menimbang rumput laut menggunakan timbangan elektrik. Parameter pendukung berupa hasil pengukuran beberapa parameter hidrologi perairan yang meliputi kecepatan arus permukaan, kecerahan, suhu, salinitas, pH, nitrat, TSS, dan BOT yang diambil per kedalaman uji, serta intensitas cahaya permukaan sebagai dasar perhitungan nilai pendugaan distribusi intensitas cahaya pada tiap kedalaman perairan menurut Hukum Beer-Lambert (Valiela, 1995). Koefisien peredupan yang diperlukan untuk pendugaan nilai intensitas cahaya pada tiap kedalaman dihitung dari pembacaan kecerahan keping Sechi disk dengan menggunakan hubungan persamaan empiris (Tilmann et al., 2000).

Analisis data pertumbuhan dilakukan dengan ANOVA untuk mengetahui apakah terdapat perbedaan yang signifikan pada faktor-faktor uji. Jika ada perbedaan yang signifikan maka dilanjutkan dengan uji Beda Nyata Terkecil (BNT). Data hidrologi perairan dianalisis secara deskriptif.

\section{HASIL DAN BAHASAN}

Hasil penelitian menunjukkan bahwa pertumbuhan rumput laut Sargassum sp. menunjukkan pola yang relatif sama di kedua lokasi penelitian. Pertumbuhan terbaik diperoleh dari unit perlakuan KODO (tanpa kantong pada permukaan perairan) dan pertumbuhan terendah diperoleh dari perlakuan K3D4 (kantong dengan ukuran mata jaring 0,25 inci pada kedalaman $200 \mathrm{~cm}$ ). Bobot tertinggi rumput laut Sargassum sp. di lokasi-I mencapai 235,8 g dan terendah 19,2 g; sedangkan di lokasi-II tertinggi mencapai 208,4 g dan terendah 42,2 g (Tabel 2).

Hasil uji analisis varian menunjukkan bahwa faktor wadah kantong, faktor kedalaman, dan interaksi kedua faktor berpengaruh terhadap pertumbuhan rumput laut Sargassum sp. di kedua lokasi pada taraf uji 5\% $(P<0,05)$. Hal ini berarti bahwa rekayasa wadah budidaya dan intensitas cahaya berpengaruh terhadap pertumbuhan Sargassum sp. Uji lanjut beda nyata terkecil (BNT) juga menunjukkan terdapat perbedaan antar perlakuan dalam satu lokasi, seperti yang ditunjukkan pada Tabel 2 terlihat adanya notasi berbeda pada unit-unit perlakuan.

Penggunaan kantong untuk budidaya rumput laut Sargassum sp. memberi efek negatif bagi pertumbuhan rumput laut (Gambar 4), karena pada 


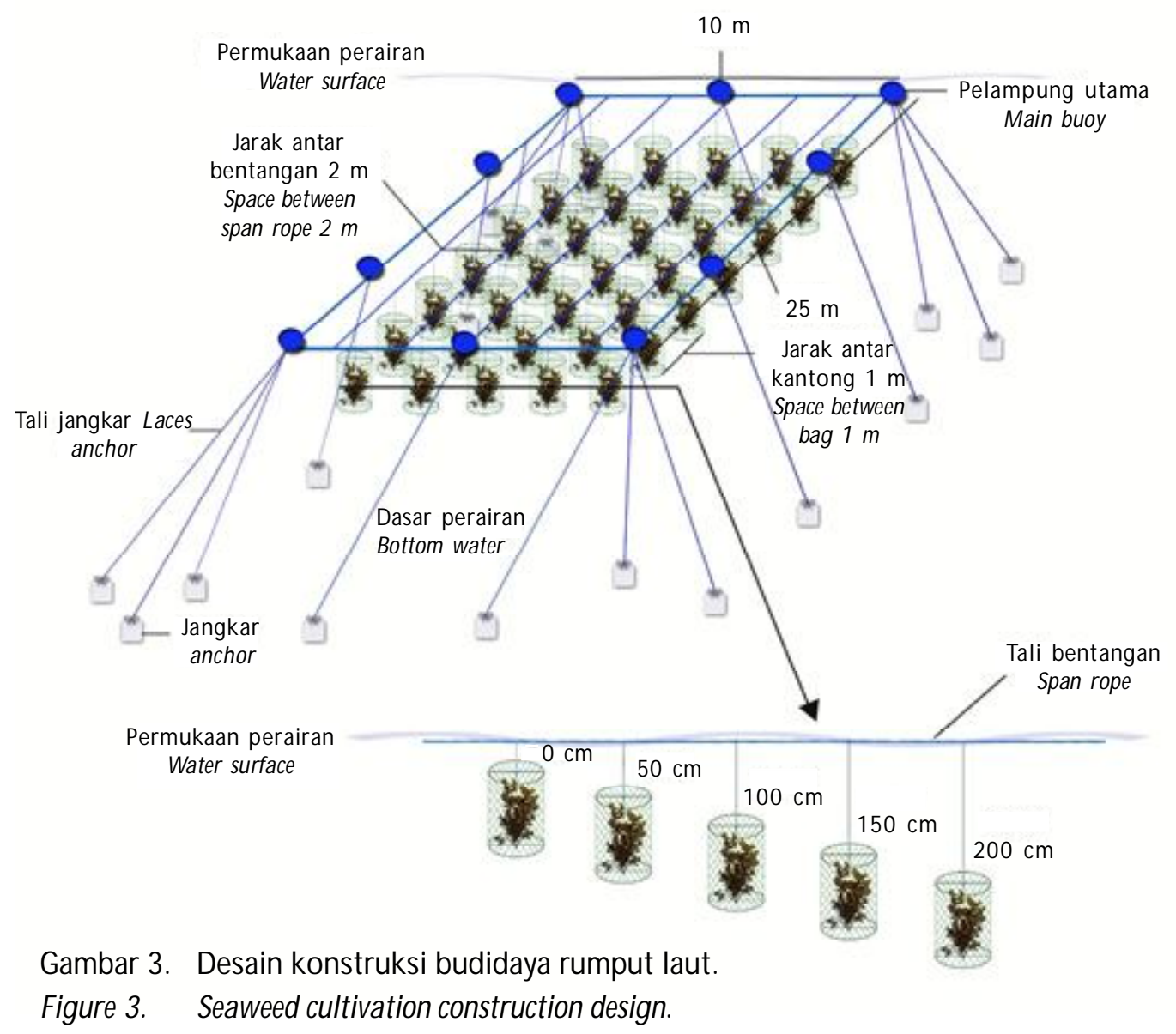

kantong-kantong tersebut terjadi penempelan suspensi perairan dan hama berupa teritip dan telur cumi-cumi (Gambar 5). Penempelan suspensi perairan dan hama menghalangi penetrasi cahaya dan nutrisi perairan yang dibutuhkan rumput laut Sargassum sp. Ukuran mata jaring wadah kantong juga berpengaruh terhadap pertumbuhan rumput laut. Rumput laut Sargassum sp. yang dipelihara dalam wadah kantong rumput laut dengan ukuran mata jaring lebih besar memberikan respons pertumbuhan lebih baik dibandingkan dengan yang dipelihara dalam wadah kantong dengan ukuran mata jaring kecil. Hal ini erat kaitannya dengan distribusi nutrisi perairan yang lebih leluasa pada wadah kantong dengan ukuran mata jaring lebih besar.

Biofouling dan predator alami dapat menjadi masalah utama dalam setiap tahap budidaya. Kelompok alga lain, serta beberapa organisme invertebrata dapat menempel pada rumput laut Sargassum budidaya, maupun pada sarana budidaya yang digunakan (Redmon et al., 2014). Kantong rumput laut dalam penelitian ini menjadi salah satu sarana budidaya yang mendapat serangan biofouling, selain tali bentangan yang juga terkena serangannya.
Pertumbuhan rumput laut Sargassum sp. secara keseluruhan terlihat lebih baik di lokasi-II. Hasil tertinggi bobot basah rumput laut Sargassum sp. di lokasi-Il lebih rendah dibandingkan hasil budidaya di lokasi-I (unit perlakuan KODO), tetapi unit-unit perlakuan lain terlihat menunjukkan pertumbuhan bobot lebih baik di lokasi-II (Tabel 2). Hal ini diduga karena kondisi perairan yang berbeda antara kedua lokasi penelitian (Tabel 3).

Karakter perairan lokasi-I yang merupakan bagian dari kawasan Teluk Tomini berbeda dengan karakter perairan lokasi-II yang berhadapan langsung dengan Laut Sulawesi. Kondisi perairan teluk kurang berarus jika dibandingkan dengan laut terbuka. Pengukuran kecepatan arus permukaan di lokasi-I menunjukkan hasil rata-rata hanya sebesar $10,15 \mathrm{~cm} /$ detik; jauh lebih rendah dibandingkan kecepatan arus di lokasi-II yang rata-rata mencapai $22,10 \mathrm{~cm} /$ detik. Indriani \& Sumiarsih (1991) menyebutkan bahwa kecepatan arus yang dianggap optimal untuk budidaya rumput laut adalah berkisar antara 20-40 cm/detik.

Nilai kecerahan perairan di lokasi-I berkisar antara 2-5 m sedangkan nilai kecerahan perairan di lokasi-II 
Tabel 2. Rerata bobot akhir rumput laut Sargassum sp. hasil budidaya dengan metode kantong di kedua lokasi penelitian

Table 2. Average of final weight of cultivated Sargassum sp. using bag method at both research sites

\begin{tabular}{ccc}
\hline $\begin{array}{c}\text { Perlakuan } \\
\text { Treatments }\end{array}$ & $\begin{array}{c}\text { Lokasi- } \\
\text { Location-I (g) }\end{array}$ & $\begin{array}{c}\text { Lokasi-II } \\
\text { Location-I (g) }\end{array}$ \\
\hline K0D0 & $235.8 \pm 32.12^{\mathrm{e}}$ & $208 \pm 9.31^{\mathrm{j}}$ \\
K0D1 & $133.2 \pm 12.43^{\mathrm{de}}$ & $166 \pm 6.31^{\mathrm{i}}$ \\
K0D2 & $122.6 \pm 3.10 \mathrm{~d}$ & $137.4 \pm 1.32^{\mathrm{h}}$ \\
K0D3 & $111.4 \pm 8.18^{\mathrm{d}}$ & $132.6 \pm 4.00^{\mathrm{h}}$ \\
K0D4 & $105.2 \pm 2.39^{\mathrm{d}}$ & $128.6 \pm 11.52^{\mathrm{h}}$ \\
K1D0 & $58 \pm 10.43^{\mathrm{bc}}$ & $99.6 \pm 2.24^{\mathrm{g}}$ \\
K1D1 & $60.4 \pm 7.69^{\mathrm{c}}$ & $89.8 \pm 1.39^{\mathrm{fg}}$ \\
K1D2 & $51 \pm 5.23^{\mathrm{bc}}$ & $77.8 \pm 1.59^{\mathrm{def}}$ \\
K1D3 & $50.2 \pm 8.26^{\mathrm{bc}}$ & $76.8 \pm 4.32^{\mathrm{def}}$ \\
K1D4 & $36.2 \pm 8.02^{\mathrm{abc}}$ & $68.6 \pm 2.29^{\mathrm{bcd}}$ \\
K2D0 & $52.6 \pm 7.42^{\mathrm{bc}}$ & $91.4 \pm 0.92^{\mathrm{fg}}$ \\
K2D1 & $48.8 \pm 12.02^{\mathrm{bc}}$ & $86 \pm 1.26^{\mathrm{efg}}$ \\
K2D2 & $40.6 \pm 8.94^{\mathrm{abc}}$ & $84.8 \pm 2.05^{\mathrm{ef}}$ \\
K2D3 & $34.8 \pm 8.85^{\mathrm{abc}}$ & $60.8 \pm 1.77^{\mathrm{bc}}$ \\
K2D4 & $45.2 \pm 5.32^{\mathrm{abc}}$ & $55.6 \pm 1.50^{\mathrm{ab}}$ \\
K3D0 & $30.2 \pm 4.61^{\mathrm{ab}}$ & $82.4 \pm 3.72^{\mathrm{ef}}$ \\
K3D1 & $34.4 \pm 4.34^{\mathrm{abc}}$ & $80 \pm 4.85^{\mathrm{def}}$ \\
K3D2 & $32.6 \pm 7.33^{\mathrm{abc}}$ & $73.2 \pm 6.95^{\mathrm{cde}}$ \\
K3D3 & $30.2 \pm 4.36^{\mathrm{ab}}$ & $55.6 \pm 2.50^{\mathrm{ab}}$ \\
K3D4 & $19.2 \pm 3.00^{\mathrm{a}}$ & $42.2 \pm 7.76^{\mathrm{a}}$ \\
\hline
\end{tabular}

Keterangan: Nilai pada kolom yang sama dan diikuti oleh huruf yang sama menunjukkan tidak berbeda nyata $(P>0,05)$

Notes: $\quad$ The values in the same coloumn followed by the same superscript arenot statistically significantly different $(P>0.05)$

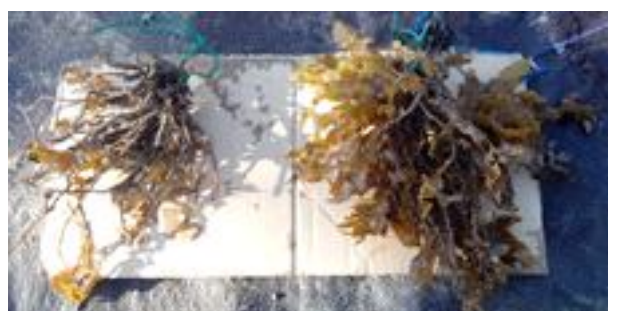

(a)

(b)

Gambar 4. Performa rumput laut Sargassum sp. hasil budidaya dengan kantong (a) dan tanpa kantong (b).

Figure 4. Performance of cultivated Sargassum sp. with bag (a) and without bag (b). 


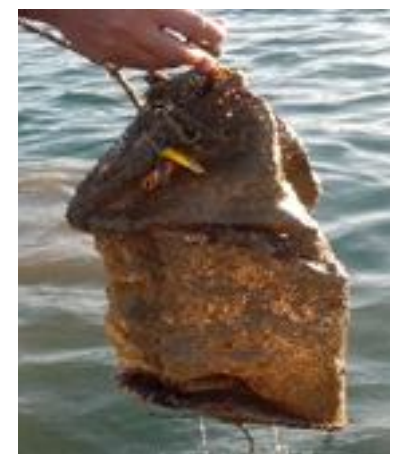

(a)

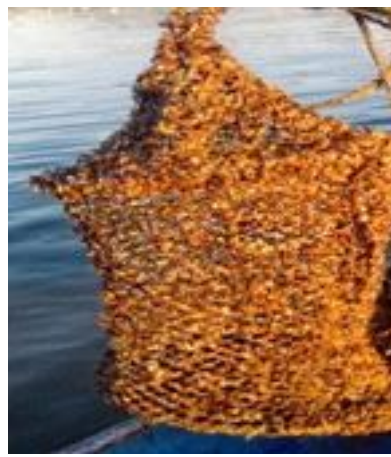

(b)

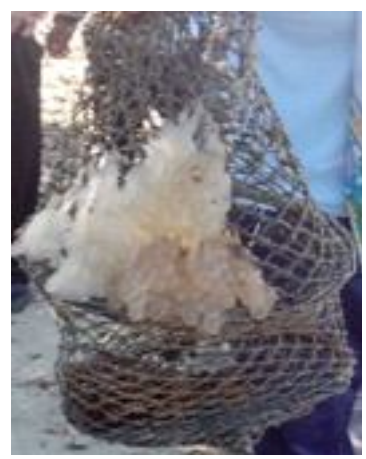

(c)

Gambar 5. Penempelan pada kantong rumput laut (a) suspensi perairan; (b) teritip; dan (c) telur cumi-cumi.

Figure 5. Attachment to seaweed bag (a) water suspensions; (b) barnacles; and (c) eggs of squid.

yakni antara 3-5 m. Effendi (2003) menyebutkan bahwa nilai kecerahan sangat dipengaruhi oleh keadaan cuaca, waktu pengukuran, kekeruhan, dan padatan tersuspensi.

Sebagai organisme fotosintetik, rumput laut Sargassum sp. mutlak memerlukan cahaya untuk mendukung pertumbuhannya. Kebutuhan intensitas cahaya matahari bagi marga Sargassum lebih tinggi daripada alga merah (Kadi, 2005). Penyerapan cahaya matahari merupakan salah satu faktor pembatas bagi pertumbuhan rumput laut sehingga faktor kedalaman menjadi hal yang penting untuk diperhatikan dalam aplikasi budidaya rumput laut Sargassum sp. Pentingnya cahaya bagi pertumbuhan Sargassum sp. dapat dilihat dari hasil penelitian ini bahwa pada hampir seluruh perlakuan menunjukkan semakin bertambahnya kedalaman berakibat pada semakin menurunnya bo bot rumput laut Sargassum sp.

Cahaya matahari merupakan sumber energi utama yang menentukan produktivitas ekosistem akuatik (Wetzel, 2001). Fotosintesis erat kaitannya dengan intensitas cahaya. Intensitas cahaya matahari akan semakin menurun dengan semakin dalamnya lapisan perairan (Warsa \& Kunto, 2011). Setiap peningkatan intensitas cahaya akan selalu diikuti peningkatan nilai produktivitas organisme fotosintetik sampai pada suatu titik optimum (Alianto et al., 2008).

Liang et al. (2013) melaporkan hasil penelitiannya terhadap S. thunbergii, dan menyimpulkan bahwa pengaturan kedalaman perairan yang erat kaitannya dengan transmisi cahaya harus disesuaikan untuk dapat mendukung pertumbuhan yang lebih cepat, karena faktor intensitas cahaya, suhu perairan, dan salinitas berpengaruh nyata terhadap kecepatan fotosintesis $(P<0,05) S$. thunbergii.

Kedalaman perairan juga erat kaitannya dengan suhu perairan. Suhu di permukaan perairan relatif lebih tinggi karena intensitas cahaya matahari juga relatif lebih kuat pada bagian permukaan perairan (Masyahoro \& Mappiratu, 2010). Hasil pengukuran suhu perairan lokasi-I berkisar antara $26^{\circ} \mathrm{C}-30^{\circ} \mathrm{C}$, lebih tinggi dibandingkan suhu perairan lokasi-II yang berkisar antara $23^{\circ} \mathrm{C}-26^{\circ} \mathrm{C}$. Hal ini berpengaruh terhadap pertumbuhan rumput laut Sargassum sp. menjadi lebih baik di lokasi-Il. Liang et al. (2013) melaporkan bahwa pengaruh suhu perairan terhadap kecepatan fotosintesis terkait dengan pola kerja enzim. Suhu perairan yang terlalu rendah atau terlalu tinggi menyebabkan pertumbuhan yang kurang baik bagi S. thunbergii yang diuji dalam skala laboratorium. Kerja enzim yang berperan sebagai katalisator proses fotosintesis tidak dapat bekerja dengan baik pada suhu yang terlalu rendah atau terlalu tinggi. Laju fotosintesis menurun secara signifikan pada suhu $\leq$ $10^{\circ} \mathrm{C}$ dan $\geq 28^{\circ} \mathrm{C}$. Zhang et al. (2009) juga menjumpai hasil yang sama pada penelitiannya terhadap $\mathrm{S}$. hornerito.

Pengukuran salinitas lokasi-I berkisar antara 3435 ppt, sedikit lebih tinggi jika dibandingkan salinitas lokasi-Il yang berkisar antara 32-33 ppt. Menurut Kadi (2005), marga Sargassum tumbuh subur pada daerah tropis dengan salinitas 32-33,5 ppt. Liang et al. (2013) menambahkan bahwa rumput laut memproduksi lebih banyak energi untuk mampu bertahan pada kondisi salinitas yang tidak optimal. Paparan salinitas ekstrem rendah maupun tinggi memberikan efek yang signifikan terhadap laju fotosintesis. 


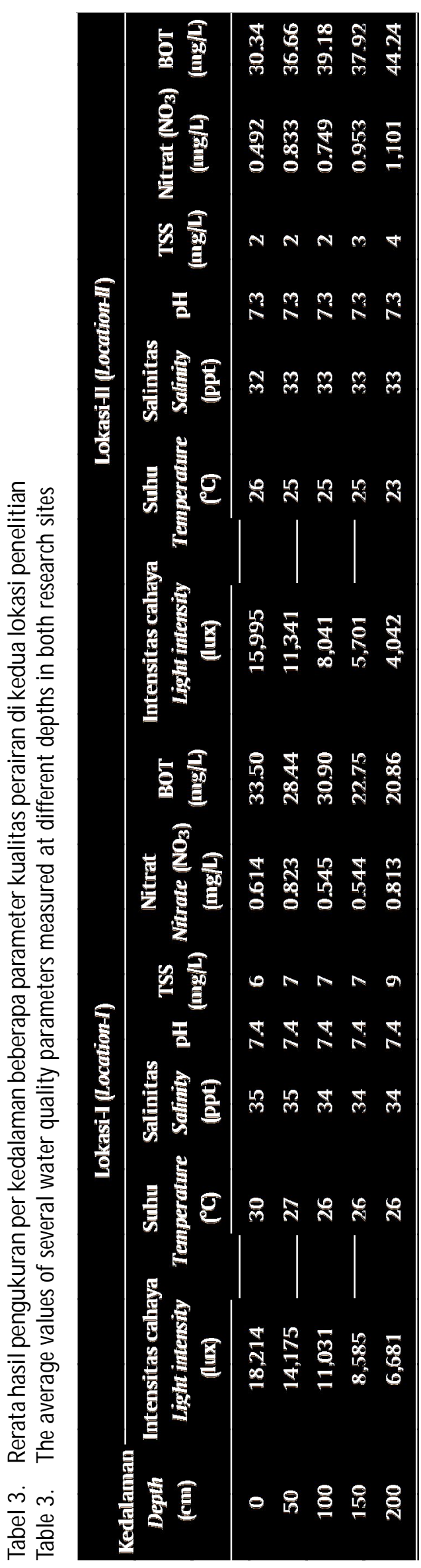


Derajat keasaman $(\mathrm{pH})$ perairan memengaruhi toksisitas suatu perairan. Sebagian besar organisme akuatik sensitif terhadap perubahan $\mathrm{pH}$. Rumput laut umumnya dapat tumbuh dengan baik pada kisaran $\mathrm{pH}$ 6,5-9,5 (Djurjani, 1999 dalam Asni, 2015). Nilai pH perairan di kedua lokasi budidaya stabil dan masih dalam kisaran normal sehingga tidak menjadi faktor pembatas pertumbuhan rumput laut Sargassum sp. di kedua lokasi.

Padatan tersuspensi total (total suspended solid) terdiri atas lumpur dan pasir halus, serta jasad-jasad renik, yang terutama disebabkan oleh kikisan tanah atau erosi tanah yang terbawa ke badan air. Kandungan TSS menyebabkan rendahnya tingkat kecerahan air laut. Kandungan TSS yang tinggi mengurangi penetrasi cahaya matahari ke dalam laut sehingga cahaya permukaan yang diterima tidak cukup efektif untuk fotosintesis (Connel \& Miller, 1995). Kandungan TSS lokasi-I jauh lebih tinggi dibandingkan lokasi-II, menyebabkan tingkat kecerahan perairan lokasi-I lebih rendah walaupun rata-rata intensitas cahaya permukaan yang diterima lebih besar dibandingkan lokasi-II.

Nitrat merupakan sumber nitrogen bagi tumbuhan yang selanjutnya dikonversi menjadi protein. Azman (2005) dalam Hendrajat et al. (2010) bahwa nitrat akan menjadi faktor pembatas jika konsentrasinya $<0,1$ dan $>4,5 \mathrm{mg} / \mathrm{L}$. Kadar nitrat perairan di kedua lokasi penelitian masih dalam kisaran nilai tersebut, sehingga bukan menjadi faktor pembatas pertumbuhan rumput laut Sargassum sp.

Konsentrasi tertinggi bahan organik terlarut terdapat pada permukaan perairan dan terutama perairan dekat pantai. Bahan organik terlarut yang ideal untuk budidaya yaitu pada kisaran 20-30 mg/L (Rakhman, 1999).

Ketidakberhasilan metode kantong untuk diterapkan pada budidaya rumput laut Sargassum sp. membuka peluang untuk dilakukan penelitian lebih lanjut untuk menggali lebih dalam informasi yang diperlukan bagi pengembangan budidaya rumput laut Sargassum sp. Penerapan metode longline dapat dikaji lebih jauh untuk melengkapi informasi dalam upaya pengembangan budidaya Sargassum sp. dengan tidak menutup kemungkinan penerapan metode budidaya lainnya.

\section{KESIMPULAN}

Penggunaan kantong rumput laut kurang efektif dalam memacu pertumbuhan rumput laut Sargassum $\mathrm{sp}$. Pertumbuhan sangat dipengaruhi oleh intensitas cahaya, karenanya budidaya Sargassum sp. perlu memperhatikan faktor kedalaman perairan yang berkorelasi dengan intensitas cahaya matahari.

\section{UCAPAN TERIMA KASIH}

Terima kasih kepada Loka Riset Budidaya Rumput Laut (LRBRL), Dinas Kelautan dan Perikanan Kabu paten Pohuwato Provinsi Gorontalo, Dinas Kelautan dan Perikanan Kabupaten Bolaang Mongondow Utara Provinsi Sulawesi Utara, serta seluruh tim peneliti dan teknisi LRBRL yang berperan bagi terlaksananya kegiatan penelitian.

\section{DAFTAR ACUAN}

Alianto, Adiwilaga, E.M., \& Damar, A. (2008). Produktivitas primer fitoplankton dan keterkaitannya dengan unsur hara dan cahaya di perairan Teluk Banten. Jurnal IImu-ilmu Perairan dan Perikanan Indonesia, 15(1), 21-26.

Asni, A. (2015). Analisis produksi rumput laut (Kappaphycus alvarezii) berdasarkan musim dan jarak lokasi budidaya di Kabupaten Bentaeng. Jurnal Akuatika, 4(2), 140-153.

Connel, W.D. \& Miller, G.J. (1995). Kimia dan ekotoksikologi pencemaran. Terjemahan: Yanti Koestoer. Jakarta: Universitas Indonesia.

Effendi, H. (2003). Telaah kualitas air bagi pengelolaan sumber daya dan lingkungan perairan. Jakarta: Kanisius.

Hendrajat, E.A., Pantjara, B., \& Mangampa, M. (2010). Polikultur udang vaname (Litopenaeus vannamei) dan rumput laut (Gracilaria verrucossa). Prosiding Forum Inovasi Teknologi Akuakultur. Jakarta, Indonesia: Badan Penelitian dan Pengembangan Kelautan dan Perikanan, Pusat Penelitian dan Pengembangan Perikanan Budidaya, hlm. 145-150.

Indriani, H. \& Sumiarsih, E. (1991). Rumput laut. Jakarta: Penebar Swadaya.

Kadi, A. (2005). Beberapa catatan kehadiran marga Sargassum di perairan Indonesia. Oseana, 30(4), 19-29.

Liang, Z., Sun, X., Wang, F., Wang, W., \& Liu, F. (2013). Impact of environmental factors on photosynthesis and respiration of young seedling of Sargassum thunbergii (Sargassaceae, Phaeophyta). American Journal of Plvant Sciences, 4, 27-33.vv

Masyahoro \& Mappiratu. (2010). Respons pertumbuhan pada berbagai kedalaman bibit dan umur panen rumput laut Eucheuma cottonii di perairan Teluk Palu. Media Litbang Sulteng III, 2, 104-111.

Nisizawa, K. (2002). Seaweed kaiso. Kochi, Japan: Japanese Seaweed Association.

Puslat KP. (2011). Pemerintah Kabupaten Bolaang Mongondow Utara lirik budidaya rumput laut. Diperoleh dari website Pusat Pelatihan Kelautan dan Perikanan Kementerian Kelautan dan Perikanan: 
www.puslatkp.kkp.go.id/puslatweb/ berita. php? mod = view\&id= NWID000053

Rakhman, A. (1999). Studi penyebaran bahan organik pada berbagai ekosistem di perairan Pantai Pulau Bonebatang. Universitas Hassanuddin, Makassar.

Redmon, S., Kim, J.K., Yarish, C., Pietrak, M., \& Bricknell, I. (2014). Culture of Sargassum in Korea: Techniques and potential for culture in the U.S. Maine Sea Grant College Program. Seagrant. Retrieved from: www.seagrant.umaine.edu/files/ pdf-global/SargassumManual_062614.pdf

Sambuari, S.S., Rumate, V., \& Siwu, H. (2015). Analisis sektor basis di Kabupaten Bolaang Mongondow Utara. Jurnal Berkala IImiah Efisiensi, 15(04), 148159.

Suhaimi, R.A., Makmur, \& Mustafa, A. (2012). Evaluasi kesesuaian lahan untuk budidaya rumput laut (Kappaphycus alvarezii) di kawasan pesisir Kabupaten Pohuwato Provinsi Gorontalo. Prosiding Indoaqua - Forum Inovasi Teknologi Akuakultur. Jakarta, Indonesia: Badan Penelitian dan
Pengembangan Kelautan dan Perikanan, Pusat Penelitian dan Pengembangan Perikanan Budidaya, hlm. 827-840.

Tillmann, U.K., Hesse, K.J., \& Colijn, F. (2000). Planktonic primary production in the German Wadden sea. Journal Plankton Res., 22(7), 1253-1276.

Valiela, I. (1995). Marine ecological processes. Second Edition. New York: Springer-Verlag.

Warsa, A. \& Kunto, P. (2011). Efisiensi pemanfaatan energi cahaya matahari oleh fitoplankton dalam proses fotosintesis di Waduk Malahayu. Bawal, 3(5), 311-319.

Wetzel, R.G. (2001). Limnology: Lake and river ecosystem. Third Edition. Philadephia: Academic Press.

Zhang, Y.R., Liu, F., Shan, T.F., \& Pang, S.J. (2009). Stress resistance of young seedling of Sargassum hornerito a veriety of temperatures, irradiance and salinities revealed by chlorophyll fluoresence measurements. South China Fisheries Sience, 5(2), 1-9. 